\title{
Nutrition and poverty in industrialized countries: report of roundtable discussion
}

\section{BY J. L. BUTTRISS}

\author{
National Dairy Council, 5-7 John Princes Street, London W1M OAP
}

The report of the Nutrition Task Force's Low Income Project Team (LIPT) was published in early 1996. The report, Low Income, Food, Nutrition and Health: Strategies for Improvement (Department of Health, 1996), contains far-ranging recommendations, as discussed by Nelson (1997). The principal recommendations were: to develop a coordinated national approach on food and low income, to establish local food partnerships, to set-up a national network and database on food and low income. Shortly after its publication, a wide range of organizations with an interest in poverty and nutrition were invited to attend a forum in London in May 1996 on Tackling the Problems of Diet and Health in Low Income Families, convened by the Chairman of LIPT, with the objective of carrying forward the recommendations. The ensuing discussions identified the need for the work of LIPT to continue via a cross-sectional forum, including representatives of local and national government, and constraints to progress which need to be addressed (Table 1).

Questions that emerged from the discussions included: how can we bridge the gaps? what are the barriers to progress? what is the nutritional agenda, and how can this be communicated? how can we effect the shift from consumerism to citizenship?

These questions, together with the constraints listed in Table 1, formed the basis of the roundtable discussion. To assist the discussion, some of the constraints were translated into the examples listed in Table 2.

Table 1. Constraints to progress in tackling the problems of diet and health in low-income families

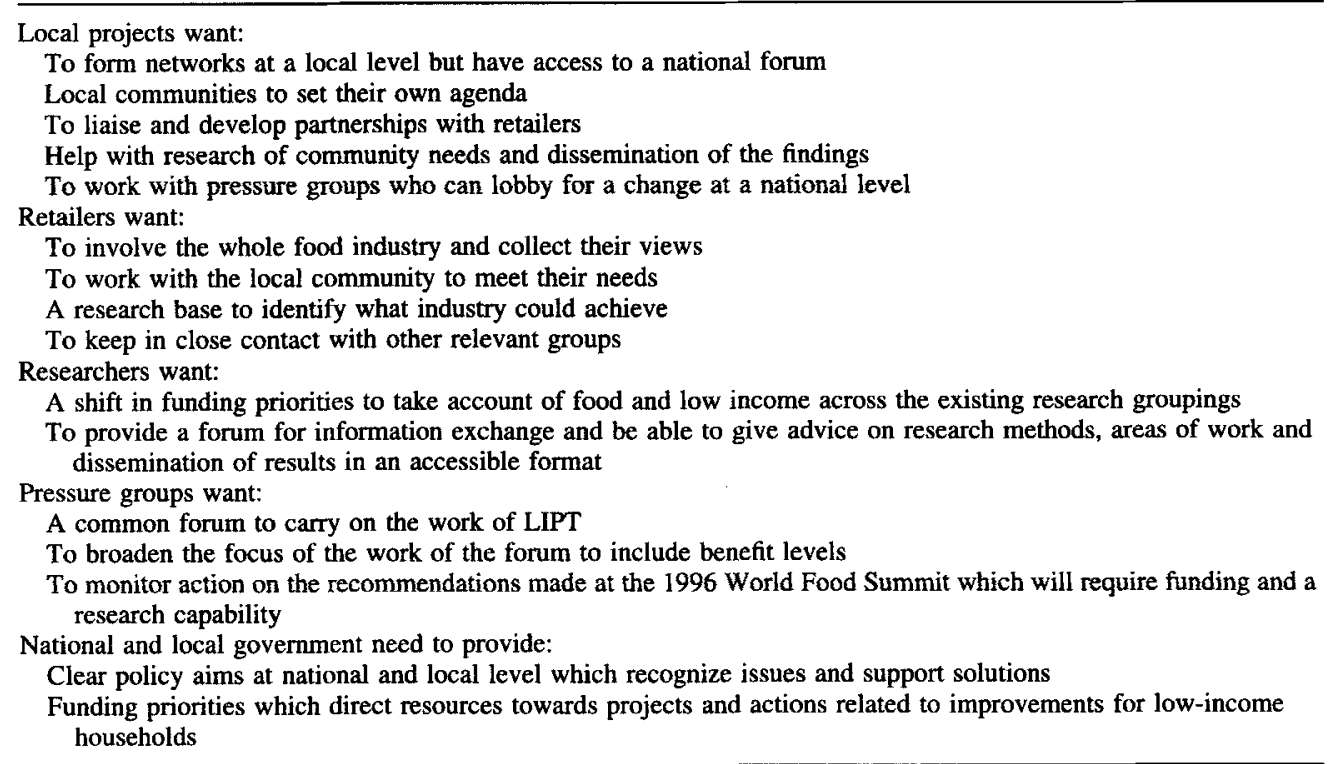


Table 2. Examples of constraints and associated questions which need to be addressed in tackling the problems of diet and health in low-income families

\begin{tabular}{lll}
\hline \hline $\begin{array}{l}\text { Local projects, } \\
\text { community initiatives }\end{array}$ & $\begin{array}{c}\text { Collaboration, evaluation, need } \\
\text { for local and national indicators } \\
\text { What is the research agenda? }\end{array}$ & University departments \\
$\begin{array}{l}\text { National nutrition } \\
\text { guidelines }\end{array}$ & $\begin{array}{l}\text { Need for a clear, concise and } \\
\text { targeted nutrition message } \\
\text { Who are the poor? } \\
\text { What is the message? }\end{array}$ & $\begin{array}{c}\text { Series of appropriately } \\
\text { targeted messages }\end{array}$ \\
$\begin{array}{l}\text { Retailers } \\
\text { Access to an affordable healthy diet }\end{array}$ & Consumers \\
$\begin{array}{l}\text { Do retailers have a social } \\
\text { responsibility? }\end{array}$ & \\
$\begin{array}{l}\text { Lack of cooking skills, } \\
\text { basic equipment } \\
\text { and general 'food' } \\
\text { knowledge }\end{array}$ & $\begin{array}{l}\text { Provision of cooking skills via } \\
\text { local projects, national } \\
\text { curriculum, better use of } \\
\text { existing local resources } \\
\text { What is stopping schools } \\
\text { being a focus for local activity? }\end{array}$ & $\begin{array}{c}\text { Confidence in preparing } \\
\text { economical yet healthy } \\
\text { food for the family }\end{array}$ \\
\hline \hline
\end{tabular}

Speakers were invited to address some of the examples and the discussion was broadened with input from the audience. The discussion was far-ranging and referred to the fact that the subject of food and poverty is broader than simply being a matter of nutrition; other sectors need to be involved if improvements in nutrition are to be made, in particular those sectors concerned with finance. However, local food projects remain important, especially through their influence on empowerment, although they may have only a relatively small impact in terms of the number of individuals reached.

Whilst it was acknowledged that there is a need for university departments and those involved in local projects to work more closely together for their mutual benefit, tension can be expected. For example, in relation to respective interests in evaluation $v$. a functioning project. However, some workers have overcome these hurdles, and examples of good practice were mentioned.

Lack of cooking skills was seen as a major problem, with one speaker suggesting that the food chain disenfranchises people, who are led to believe that cooking skills are no longer necessary with the plethora of good-quality, ready-prepared foods available these days.

Changes in domestic science provision in schools were deplored and the need for acquisition of basic cooking skills supported. The value of simple cookery programmes on television, demonstrating recipes that can be produced from economical ingredients was strongly supported.

A plea was made for the use of more food cartoons and captions as a means for communicating the key messages in a simple but clear way.

Developing the concept of 'good life' was considered to be a useful way forward. It was also considered to be important to recognize the diversity of food cultures present in 
society and the importance of food sharing common to many of these. Top-down projects can undermine existing diversity and sharing patterns. Academics need to reconsider the language used to communicate information about food and health with the community at large.

Professor Riches stressed that poverty is not a party political issue and there is a need for the whole of society to change its attitude. Inequalities in health are getting wider and it was suggested that a 'them and us' attitude concerning those in poverty and those out of poverty, is strengthening. Furthermore, relative poverty can affect many in society, albeit transiently in many cases, e.g. students, divorced or separated families, families temporarily out of work, elderly people etc.

Organizations such as food co-ops were applauded, but one speaker doubted whether the retailers had social responsibility high on their list of priorities, although many of their commercial activities benefit consumers (e.g. buying up small shops in deprived areas to prevent them closing).

A plea for the return of school milk for all children was made (subsidized milk is now available for primary school children only). Many children go to school having had no breakfast and teachers sometimes keep cereal in the classroom for hungry children who find it hard to concentrate. School breakfast schemes are proving very popular in a number of inner city areas in Britain.

The audience were asked to consider things they, both as individuals and nutritional scientists, could do to help inform others of the issues and to help overcome the constraints to progress identified during the preceding discussion and at the forum held in London.

\section{REFERENCES}

Department of Health (1996). Low Income, Food, Nutrition and Health: Strategies for Improvement. London: H.M. Stationery Office.

Nelson, M. (1997). Developments in the UK: work of the Low Income Project Tearn. Proceedings of the Nutrition Society 56, 91-100. 